\title{
Methodology of studies for selecting engineering decisions in territory planning
}

\author{
Oleksiy Priymachenko ${ }^{1}$, Oleksandr Kobzar ${ }^{2}$ \\ Kyiv National University of Construction and Architecture \\ Povitroflotsky avenue 31, Kyiv, Ukraine, 03037 \\ 1priymachenko a@ukr.net, orcid.org/0000-0001-5125-8472 \\ ªle-vlad@ukr.net, orcid.org//0000-0001-5074-1315
}

The manuscript was received on 18.01.2018 and was accepted after revision for publication on 10.03.2018 DOI: 10.31493/tit1811.0102

\begin{abstract}
The vigorous growth of cities and reduction of free territories for building construction necessitate the development of town areas with complex geotechnical conditions. The complexity of construction in such areas causes increase of construction costs and, as a result, decrease of profitability in the real estate market and occurrence of additional risks in developing the corresponding areas. In the initial stage of design, that is, in the stage of technical-and-economic assessment, there is a need to select engineering planning decisions and to adopt the corresponding arrangement of engineering protective structures in the design area. Unavailability of an algorithm for solving this problem in the initial design stage often causes a need for redesign and for development of several design variants, and as a result, for increase of design periods and for attraction of additional costs. For this purpose, it is required to analyze factors affecting selection of engineering protective structures and use of such structures in certain development areas, as well as to develop an information model for selecting engineering protective structures for specific territories.

The practicability of anti-landslide measures is determined with consideration for the basic causes of landslides. Therefore, the priority task is to determine the causes and types of landslides.

Landslide protective structures selected with consideration for causes and types of landslides and in the next study stage is to determine the loads.

The selection of optimal landslide protective structures is based on the results of engineeringgeological studies and on the results of comparison of several design variants.
\end{abstract}

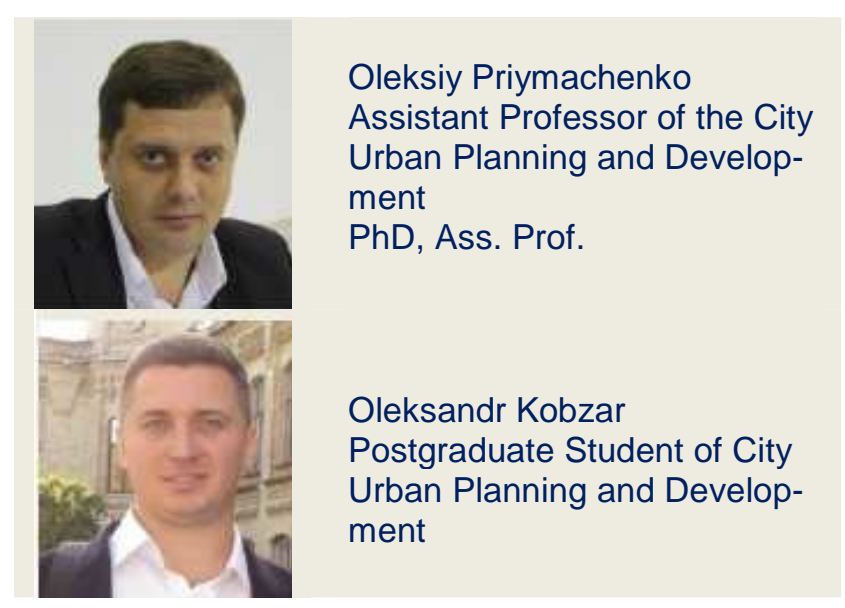

Exactly, in selecting landslide protective structures required, models can be used.

The engineering decision in territory planning should be taken by comparing variants of landslide protective structures with consideration for initial and calculated data.

The proposed information model will provide the possibility to determine, in earlier design stages, the technology and cost of construction.

The proposed methodology of studies for selecting engineering decisions in territory planning provides the possibility to predict the investment attractiveness of the development area and its profitability in the real estate market. The results obtained can be used in developing town-planning information bases for territories.

The actuality of these studies is confirmed by development density and competition among builders in taking decisions and reducing risks.

Key words: landslide, engineering protection of territories, anti-landslide measures, landslide protective structures, retaining wall, drainage. 


\section{INTRODUCTION}

The vigorous growth and associated territory development, caused by intensive industrial, civil, hydraulic and other construction, result in the development of technogenic geological processes which change the existing geoecological state of territories and cause land surface deformation.

Particularly common are exogenic gravitational processes, which occur as split-offs, landfalls, and landslides. The problems relating to landslides, magnitudes and shapes of landslides, rate of landslide masses movement, and factors affecting these problems and characteristics can be different.

According to the last data, the total amount of landslides in Ukraine is about 23 thousand and continuously changes due to removal (by cutting, cleaning, or merging) of existing landslides or formation of new landslides, Within the Kyiv Region, about 900 landslides have occurred. The problems relating to landslides are also characteristic for the right-bank side of Kyiv, where about 70 landslides have been registered.

Landslides are very dangerous for town areas and require significant expenditures for removing damage consequences and developing anti-landslide measures.

The problems relating to landslides and selection of landslide protective structures are top-priority and urgent.

The term "landslide" means a physicogeological phenomenon consisting in relatively slow or, in specific cases, fast downhill movement, under action of gravity, of earth masses over the slip base due to the change of the earth physical properties caused by surface water, underground water, or atmospheric factors [1].

The term "landslide area" means an area where rock landslide deformations occur at the current time or had occurred in the past.

The term "landslide-hazardous area" means an area where landslide deformations do not occur at the current time or had not occurred in the past but can occur under the individual or combined influence of natural or antropogenic factors.

\section{STATEMENT OF THE PROBLEM}

The purpose of this paper is to carry out the systematic analysis of landslide processes in order to solve problems relating to the development of city areas, determine new methods for solving such problems, and develop and use information models and structural diagrams designed for improving the quality and efficiency of problem solution.

There is a necessity to develop information support, perform studies, and determine science-based complex decisions and methods for selecting variants of anti-landslide measures.

\section{ANALYSIS OF THE LATEST RESEARCH AND PUBLICATIONS}

The landslides and landslide protective structures were discussed in many publications and attracted attention. At the present time, the problems relating to landslides are defined, the causes of landslides are studied, and the basic principles and methods of protection against landslides are determined.

For example, landslide processes have been studied by such researches as Bakutis V.S. [1], Vladimirov V.V. [2], Nazarenko I.I. [3] and Nishchuk V.S. [4].

\section{SYSTEMATIC ANALYSIS AND DEVELOPMENT OF MODELS FOR CLASSIFYING LANDSLIDES AND FOR ANTI-LANDSLIDE MEASURES}

The practicability of anti-landslide measures should be determined with consideration for the basic causes of landslides. Therefore, the priority task is to determine the causes and types of landslides.

The landslide-prone slope is in a boundary equilibrium state. Any violation of such state can be caused by increase of destabilizing forces, decrease of resisting forces, or, more often, by a combined effect of destabilizing and resisting forces.

The increase of destabilizing forces is characterized by the change of the stressed state of rocks of the slope or hillside, resulting in the increase of the slope or hillside gradient, 
weathering, undercutting, action of hydrostatic and hydrodynamic forces on the earth (which cause such filtration deformations as mechanical subsoil erosion, filtration protrusion, and washing), loading of the slope or hillside and adjacent areas, seismic transients, or vibrations.

The decrease of resisting forces results in the reduction of rock or earth strength, and as a consequence, in watering or bulking of the earth, formation of flowing sand, or undercutting or undermining of the slope or hillside base.

The basic factors affecting the formation of landslides are classified as natural factors and

The natural factors include climatic, geomorphological, geological, hydrogeological, hydrological, and other factors relating to geological processes (Fig.1).

The antropogenic factors include economic activity, degree of landscaping, construction works, effect of buildings and structures, and operational imperfections.

The basic parameters of landslide processes and the effect of landslide processes on the territory are discussed below in detail. The landslide classification scheme is shown in antropogenic factors, Fig. 2.

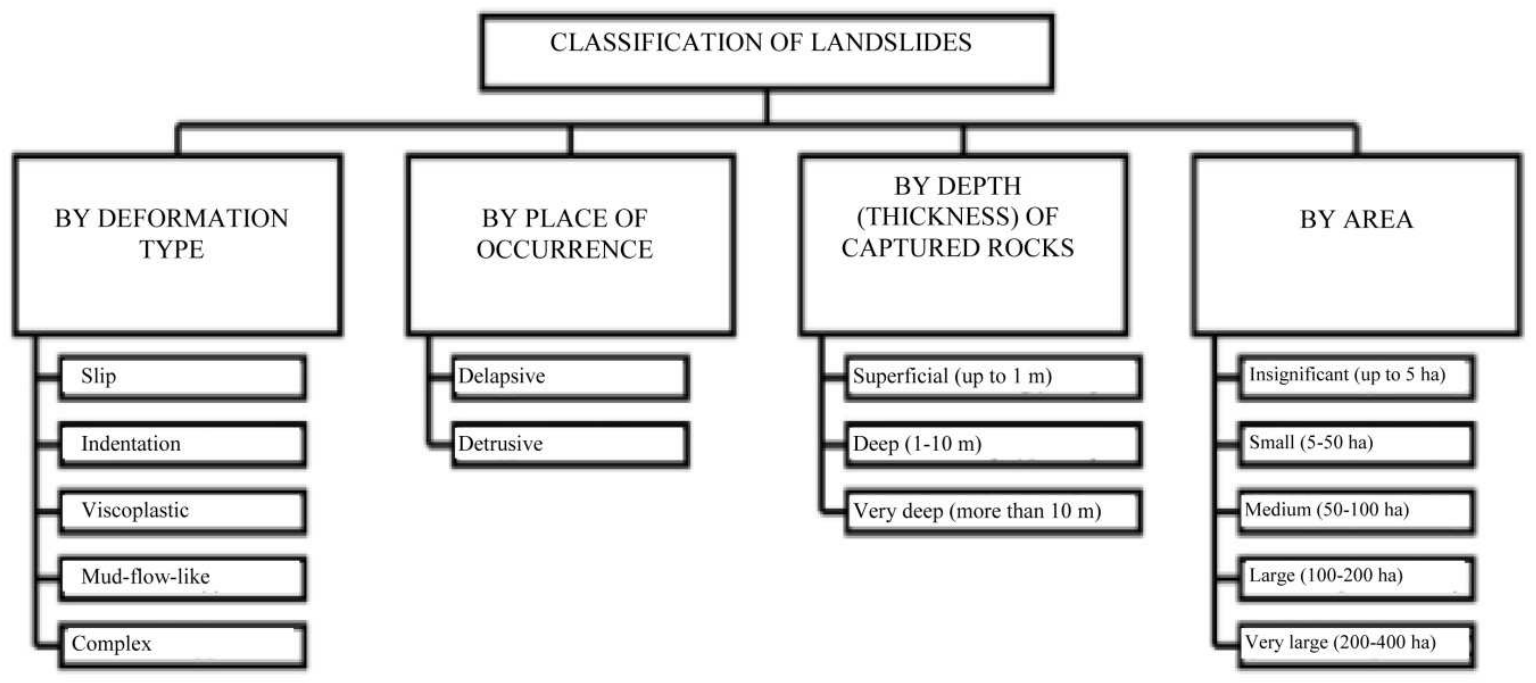

Fig.1. Causes of landslide processes

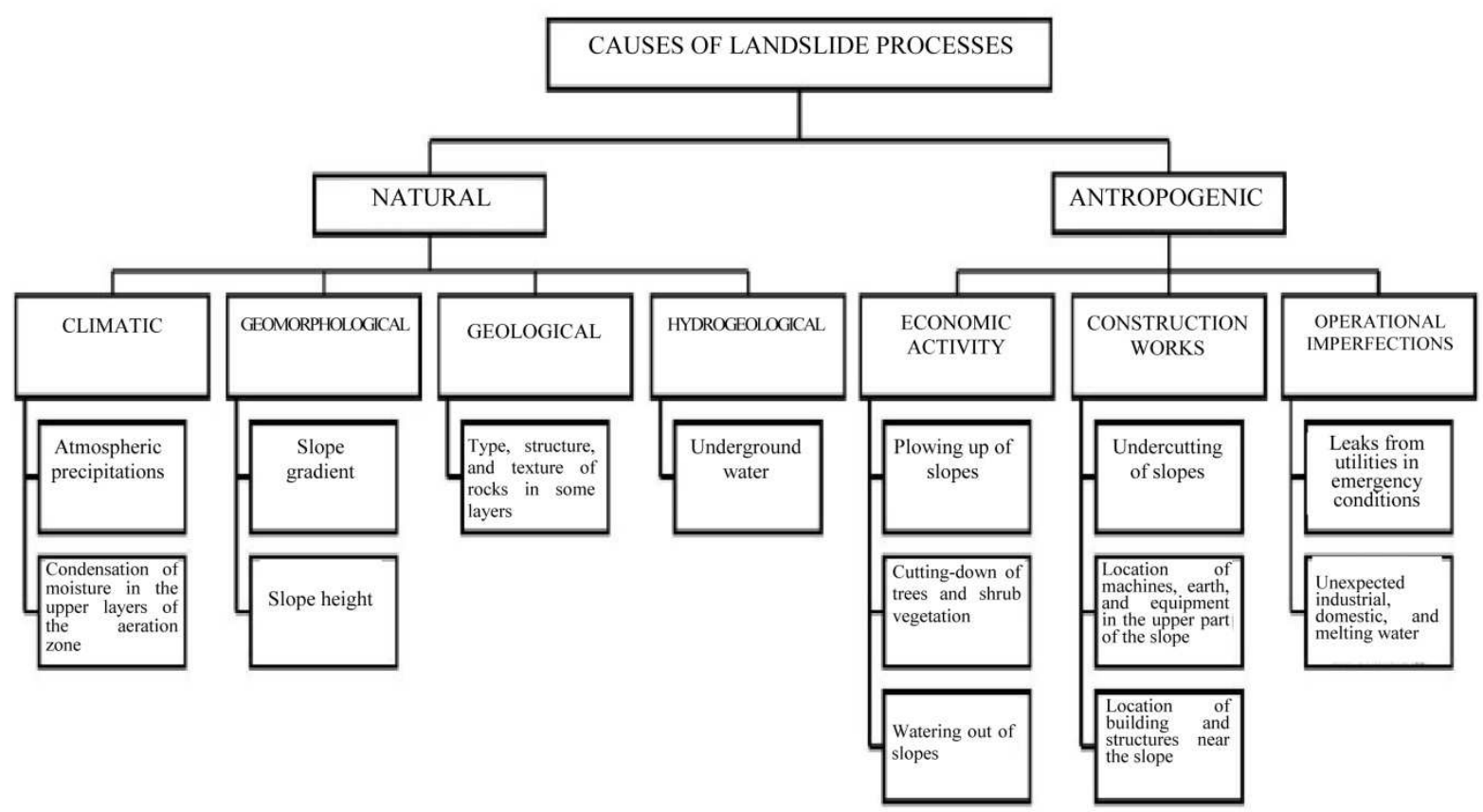

Fig.2. Classification of landslides 
Every landslide has its characteristic features, such as the landslide magnitude, rate of landslide propagation, and destructive energy.

Hereinafter, landslide protective structures will be selected with consideration for causes and types of landslides.

In the next study stage, loads caused by landslides should be determined. In landslidehazardous areas, the loads should be determined when calculating the slope stability with consideration for coincidence of adverse factors and basic, additional, and specific loads associated with landslides.

The basic loads are the following:

1. Continuous loads:

- design bulk weight of earth;

- weight of buildings and stationary structures located on the slope.

2. Temporary loads:

- weight of filled-up earth;

- weight of temporary buildings and structures, weight of equipment, wind loads, weight of snow, weight of trees

3. A single short-time load:

- weight of heavy construction machines, hoisting cranes, large-sized equipment.

The additional loads are the following:

1. Continuous additional loads.

2. Temporary additional loads.

3. Short-time additional loads.

The specific loads are the following:

1. Continuous specific loads.

2. Temporary specific loads.

3. Two short-time specific loads.

4. A single specific load:

- an emergency load, load from underground water in emergency conditions when the underground water level exceeds the level which is characterized by the low probability of occurrence;

- a seismic load.

When calculating the stability of a landslide-prone slope, the basic and emergency loads and effects of the loads should be considered. For the first group of loads (loads depending on the slope strength), the design boundary values of the basic continuous loads and effects of such loads should be considered when checking the landslide-caused loading.
When the loads have been determined, it is necessary to calculate the stability of the slope or hillside. All the methods for calculating stability of slopes and hillsides are based on the boundary equilibrium theory and on the assumption that the slope earth mass is in a stressed state and in boundary equilibrium conditions.

The stability of a slope or hillside in natural or design conditions should be calculated with consideration for the bearing capacity of the slope or hillside in boundary equilibrium conditions.

The design stability coefficient should be determined as follows (1):

$$
k_{s t}=\frac{\sum_{i=1}^{n}\left(Q_{i} \cdot \cos \alpha_{i} \cdot \operatorname{tg} \varphi_{i}+c_{s t} \cdot l_{i}\right)}{\sum_{i=1}^{n}\left(Q_{i} \cdot \sin \alpha_{i}\right)}
$$

where:

$Q_{i}$ is the weight of the earth mass of the $i$-th design element with consideration for the total load on the slope or hillside from buildings and structures $(\mathrm{kg})$;

$\mathrm{a}_{i}$ is the tilt angle of the landslide slip surface to the horizontal plane for the $i$-th design element (degree);

$\varphi_{i}$ is the angle of internal friction (degree);

$\mathrm{c}_{i}$ is the specific cohesion $(\mathrm{Pa})$;

$l_{i}$ is the length of the ith design element along the slip surface $(\mathrm{m})$.

The design stability coefficient must meet the following requirement (2):

$$
k_{s t} \geq k_{c}
$$

where:

$k_{s t}$ is the design stability coefficient;

$k_{c}$ is the normative (minimum) stability coefficient.

The $k_{s t}$ value characterizes the degree of stability of the slope or hillside. If $k_{s t}>1$, the slope or downhill is considered as stable. If $k_{s t}<1$, the stability of the slope or hillside is violated and a landslide occurs. If the $\mathrm{k}_{s t}$ value is approximately equal to 1 , this value corresponds to the boundary equilibrium state of the earth mass and, as a result, to the possibility of a landslide [8].

The $k_{\text {st }}$ values for basic loads associated with landslide-prone and landslide-hazardous slopes should be 1.35 and 1.25 , correspondingly, for the first category of importance of buildings 1.3 and 1.25 , correspondingly, for 


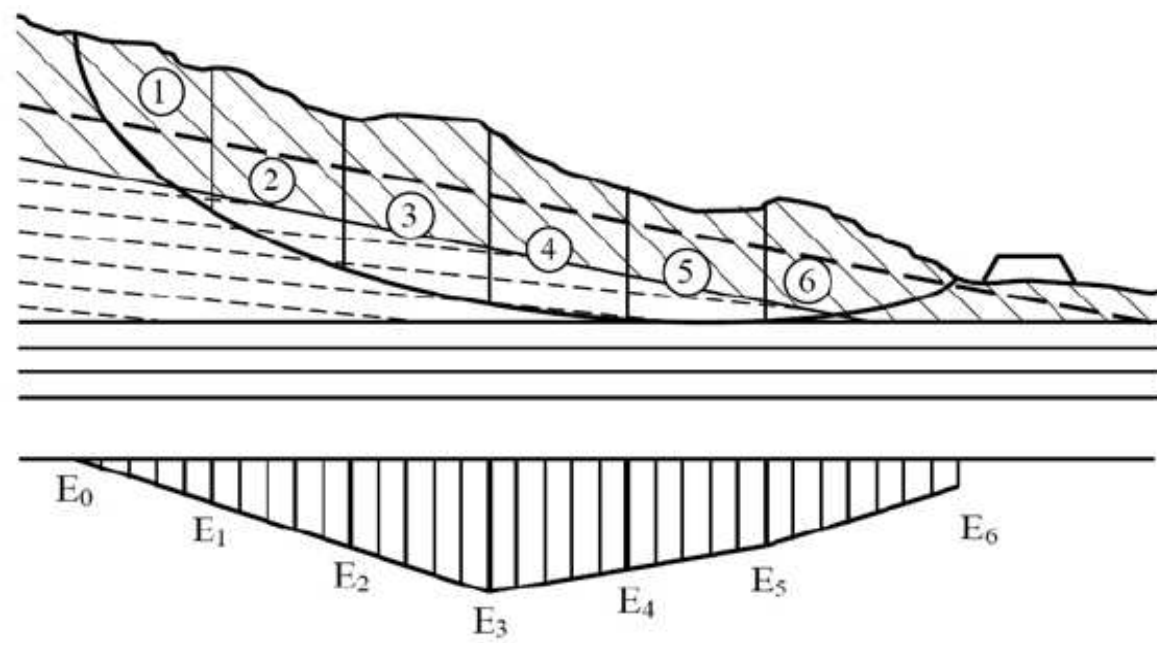

Fig.3. Landslide pressure diagram

the second category of importance of buildings, 1.25 and 1.15 for the third category of importance of buildings and 1.2, and 1.1, correspondingly, for the fourth category of importance of buildings.

The kst value for specific loads should be 1.3 and 1.22, correspondingly, for the first category of importance of buildings 1,125 and 1.15 , correspondingly, for the second category of importance of buildings 1.2 and 1.1 for the third category of importance of buildings, and 1.15 and 1.05, correspondingly, for the fourth category of importance of buildings. [4], [7].

When designing landslide protective structures, it is required to determine landslide pressure E (3) and plot a landslide pressure diagram by using a method of horizontal forces (Fig.3) [8, 9].

$$
E_{i}=F_{i} \cdot \cos \alpha_{i}-\frac{\gamma_{c}}{\gamma_{n} \gamma_{f c}} R_{i} \cdot \cos \alpha_{i}
$$

where:

$\mathrm{F}_{i}$ is the landslide-producing force caused by the weight of the earth mass with consideration for buildings and structures, located in the landslide area, and filtration pressure;

$\gamma_{n}$ is the coefficient of safety against loading;

$\gamma_{f c}$ is the coefficient of importance of buildings and structures in conditions with combined loads;

$\gamma_{c}$ is the service coefficient;

$\mathrm{R}_{i}$ is the resistance of the earth mass, which should be determined with consideration for frictional forces and coalescence of earth particles (for landslide-hazardous slopes) or with consideration for only frictional forces (for landslide-prone slopes).

The selection of optimal landslide protective structures should be based on the results of engineering-geological studies and on the results of comparison of several design variants.

The basic landslide protective structures are the following (Fig.4):

- landslide restraining structures;

- retaining and supporting building foundations;

- structures for controlling surface yield and water drainage systems;

- structures for controlling underground water level.

Landslide restraining structures should be used for fixing slopes and preventing land-

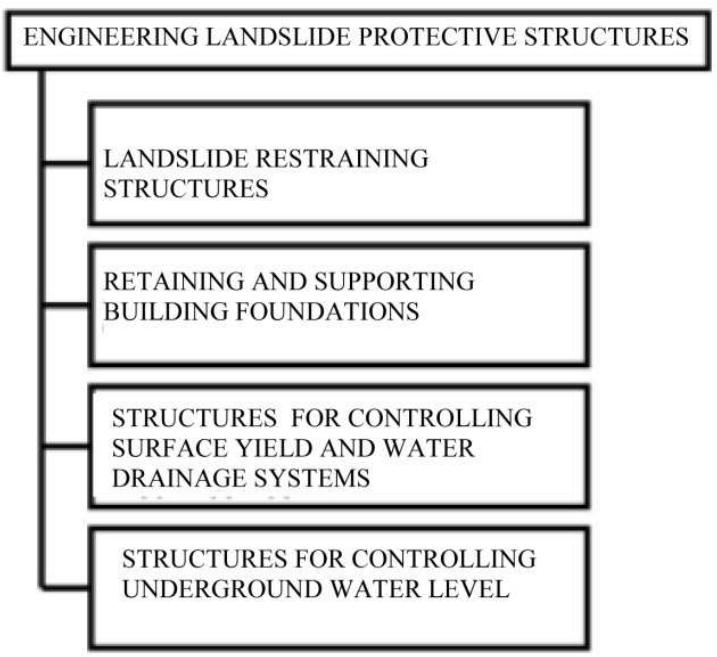

Fig.4. Engineering landslide protective structures 
slides, collapses, and inrushes. Such structures are designed for providing, individually or in combination with other landslide protective structures, the possibility to withstand landslide pressure E according to Equation (3). Landslide restraining structures should be located in such parts of landslide-hazardous or landslide-prone slopes where vertical loads acting on the possible slip surfaces create restraining forces than exceed the landslideinducing forces.

The landslide restraining structures are the following:

- retention walls on an earth or pile foundation;

- pile structures, fins, and poles designed for fixing unstable slope or hillside areas and preventing displacement of earth masses on weakened surfaces;

- anchoring structures designed as individual restraining structures with supporting plates, beams, or other elements;

- combined restraining structures.

In selecting landslide protective structures required, models can be used. The model provides the possibility to determine the type of landslide protective structures for the specific conditions and compare landslide protective structures of different types in order to select the most efficient type.

Presented below, as an example, are the results obtained by using such a model. The proposed model allows the practicability of the landslide protective structures to be determined (Fig.5).

The basic groups of factors in models are a group of natural factors and a group of perspective factors. These factors directly affect the selection of landslide protective structures.

The engineering decision in territory planning should be taken by comparing variants of landslide protective structures with consideration for initial and calculated data. In accordance with the model, the definite protection structure from each group, which is optimal as compared with the other landslide protection structures, should be adopted.

When comparing landslide protection structures, the utilization efficiency coefficient should be determined as follows (4):

$$
K_{e f . v .}=\sum\left(k_{1}+k_{1}+\ldots+k_{n}\right) / n
$$

where:

$n$ is the number of characteristics in the model;

$k_{1}+k_{2}+\ldots+k_{n}$ is the value of the corresponding characteristic in the model;

$\Sigma$ is the sum of the values of the corresponding characteristics:

$$
k_{1}+k_{1}+\ldots+k_{n} \quad k=\left\{\begin{array}{l}
k=1,0 \\
k=0,5 \\
k=0
\end{array}\right\}
$$

The value $k=1,0$ means that the use of the landslide protecting structure is efficient, and the structure is recommended for protection.

The value $k=0,5$ means that the use of the landslide protecting structure is allowable for protection if the structure is strengthened.

The value $k=0$ means that the use of the landslide protecting structure is low-efficient and is not recommended for protection.

\section{CONCLUSIONS}

According to the study results and experience gained in theoretical and practical activities in the area of town development and territory planning, proposed are classification systems for landslide processes and causes of landslide processes. These systems provide the basis for obtaining new scientific results.

The results of analysis of domestic and foreign publications has demonstrated that, at the present time, activities for determining new methods of selection of landslide protective structures in the area of town development are continued.

On the basis of analysis of the State Building Regulation and scientific and methodical literature, determined are basic measures for protecting town territories against landslides.

In order to determine optimal landslide protective structures and actions, developed is the new methodology of stepwise use of the developed models and structural diagrams.

The study performed has resulted in recommendations relating to the selection of engineering facilities for protecting town territories. 


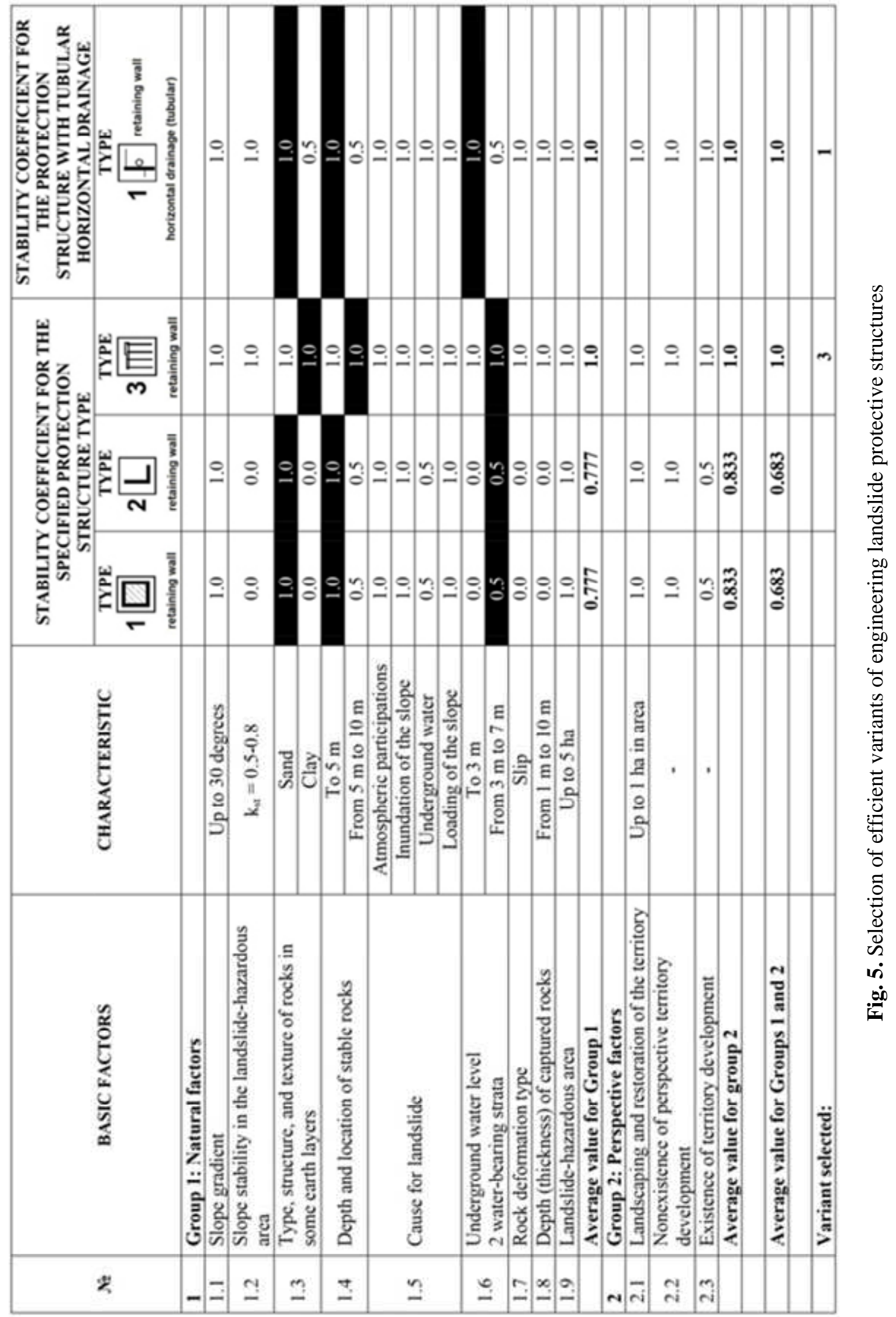


The consideration of factors having an effect on landslide processes provides the possibility to determine activities required for landslide protection of landslide-prone and landslide-hazardous territories in specific conditions and to objectively estimate engineering decisions relating to territory planning.

The proposed landslide protection actions provide the possibility to meet town development standard requirements and provide comfort living conditions for population.

\section{REFERENCES}

1. State Construction Norm 360-92. City and City Planning. Planning and Development of Urban and Rural Settlements. Kyiv, Derzhbud Ukrainy, 113 (in Ukrainian).

2. Zolotoryova R.S., 1981. Landslides - Studies and protection. Moscow, Mir, 366 (in Rusasian).

3. Nayfeld L.R., 1974. Land development of bottomland and water-logged areas. Stroyizdat, Moscow, 179 (in Rusasian).

4. Vladimirov V.V., Davidyants G.N., Rastorguyev O.S., Shafran V.L., 2004. Land development and landscaping of town territories. Architektura-S, Moscow, 240 (in Rusasian).

5. Bakutis V.E., 1970. Land development of town territories. Vysshaya Shkola, Moscow, 376 (in Rusasian).

6. Demchyshyn M.H., 2004. Technogenic impact on the geological environment of territory of Ukraine. Hnozis, Kyiv, 156 (in Ukrainian).

7. Nazarenko I.I., Polchyna S.M., Nikorych V.A., 2004. Ground science. Chernivtsi, 400 (in Ukrainian).

8. Nishchuk V.S., 2000. Engineering protection and development of territories. Kyiv, Osnova, 344 (in Ukrainian).

9. Panchenko T.F., 2006. Town development Handbook of designer. 2nd edition Ukrarkhbudinform, Kyiv, 192 (in Ukrainian).

10.Kaplan L.Z., 1961. Land development of construction sites. Moscow, 152 (in Russian).

11.Moiseiev V.Y., 1974. Land development of finish-building territories. Kyiv, 276 (in Ukrainian).

12.Ananiev V.P., Potapov A.,D., 2002. Engineering geology. Moscow, 510 (in Russian).

13.State Construction Norm B.1.1-24.2009. Protection against geological processes, adverse effects, and fire - Basic design provisions, Kyiv, 69 (in Ukrainian).

14. Tytarenko V., Dombrovskii Y., Kaluhk Y., 2015. Draft building regulation State Construction Norm B.1.1-X:2015. Engineering protection of territories, buildings, and structures against landslides and landfalls. Basic design, Kyiv, Iss.01, 71 (in Ukrainian).

15.Sliusarenko Y.S., Kaliukh Y.I., Shuminskyi V.D., Tytarenko V.A. Develoment of the state building regulation Engineering protection of territories, buildings, and structures against landslides and landfalls. Basic provisions and the state standard of Ukraine Engineering protection of territories, buildings, and structures against landslides and landfalls, 195205 (in Ukrainian).

16. Priymachenko O.V., Kobzar O.V., 2012. "Engineering-geological and hydrological processes in town development. Scientific and Technical Collected Works Town development and territory planning, Kyiv National University of Construction and Architecture, Iss.46, 476-480 (in Ukrainian).

17.Priymachenko O.V., Kobzar O.V., 2013. "Importance of monitoring in systems of protection and development of town territories with complex hydrological conditions. Scientific and Technical Collected Works Town development and territory planning, Kyiv National University of Construction and Architecture, Iss.48, 359-363 (in Ukrainian).

18.Priymachenko O.V., Kobzar O.V., 2013. Use of geoinformational technologies in solving problems relating to underflooding of territories. Scientific and Technical Collected Works Town development and territory planning, Kyiv National University of Construction and Architecture, Iss.49, 440-445 (in Ukrainian).

19.Priymachenko O.V., Kobzar O.V., 2014. Principles and methods in town territory development in water-logged areas; Scientific and Technical Collected Works Town development and territory planning, Iss.52, Kyiv National University of Construction and Architecture, Kyiv, 337-341 (in Ukrainian).

20.Kobzar O.V., 2016. Principles of classification of geological processes. MOTROL, Vol.18, No.10, 101-108 (in Polish).

21.Solovei D., Sharapa S., 2014. Analysis of space-planning and design decisions for multistory framed-monolithic residential buildings. MOTROL, Vol.16, No.5, 5-18 (in Polish).

22.Polovka S., 2015. Historical information on the study of the Azov-Black Sea Region by re- 
searches in Ukraine. Underwater Technologies, Iss.02, 11-23 (in Ukrainian).

23.Hryshyn V., Hembarskyi L., Snisarenko V., 2015. Existing and perspective artificial islands and their development; Underwater Technologies, Iss.02.2015, 32-39 (in Ukrainian).

24.Polovka S., 2017. Accumulative and tectonic structures of the bottom of the west shelf of the Black Sea and their identifying characteristics; Underwater Technologies, Iss.02, 3-7 (in Ukrainian).

25. Wysoczański W., Fic S., 2017. Ecological safety and operational reliability of buildings in landslide affected areas. Underwater Technologies, Iss.06, 74-81 (in Polish).

\section{Методология исследований выбора инженерных решений при планировке территории}

\section{Алексей Приймаченко, Александр Кобзар}

Аннотация. Стремительное развитие городов и уменьшение свободных пространств под застройку провоцируют потребность освоения участков со сложными инженерногеологическими процессами. Сложность выполнения строительных процессов на соответствующих участках приводит к увеличению себестоимости строительных работ, что, в свою очередь, снижает рентабельность на рынке недвижимости и приводит к возникновению дополнительных рисков при освоении таких участков. На начальном этапе проектирования, при технико-экономическом обосновании возникает потребность в выборе планировочных инженерных решений, принятии конструктивной схемы инженерных сооружений на участке проектирования. Отсутствие алгоритма решения данной задачи на начальном этапе часто приводит к повторному проектированию и необходимости разработки нескольких вариантов, что, в свою очередь, приводит к увеличению сроков проектирования и привлечению дополнительных средств. Для решения этой задачи нужно исследовать факторы, влияющие на выбор инженерных сооружений и возможность их применения на определенных участках застройки с последующей разработкой информационной модели по выбору сооружений защиты территорий.

Целесообразность проведения противооползневых мероприятий определяется в соответствии с основными причинами проявления смещения. Первоочередной задачей является определение таких причин и разновидностей оползней. Подбор комплекса противооползневых мероприятий проводится с учетом причин возникновения и типа оползней, а следующим этапом является определение нагрузок.

Выбор оптимального комплекса сооружений инженерной защиты выполняется на основании собранных инженерно-геологических расчетов и сравнения нескольких вариантов.

Именно для определения концептуального решения комплекса противооползневых сооружений можно использовать моделирование. Принятие инженерно-планировочного решения происходит при сравнении вариантов сооружений, учитывая исходные и расчетные данные.

Предложенная модель позволит на ранних стадиях проектирования определить технологию выполнения строительных работ, и соответственно, определит стоимость строительномонтажных работ.

Предложенная методология исследований выбора инженерных решений при планировании территории дает возможность спрогнозировать инвестиционную привлекательность участка застройки и ее рентабельность на рынке недвижимости. Полученные результаты можно применять при создании информационных градостроительных баз территорий.

Актуальность данных исследований подтверждается имеющейся плотностью застройки и конкурентностью между застройщиками в скорости принятия решений и уменьшении рисков.

Ключевые слова: оползни, инженерная защита территорий, противооползневые мероприятия, удерживающие противооползневые сооружения, подпорная стенка, дренаж. 